International Research Journal of Shariah, Muamalat and Islam (IRJSMI)

Journal Website: http://irjsmi.com/ eISSN: 2682-8553

\title{
MISCONCEPTION ABOUT ISLAM: AS A CAUSE FOR EMERGENCE OF INSURGENCY IN NIGERIA, BOKO HARAM GROUPS A CASE STUDY
}

\author{
Dr. Yunus Jibril Hassan ${ }^{1}$, Dr. Nura Ahmad ${ }^{2}$, Musbahu Saminu Tsanyawa ${ }^{3}$
}

1 Department of Islamic Studies, Federal University, Gashua, Yobe State, Nigeria

Email: Mayyaszaw11@gmail.com

2 Department of Islamic Studies, Federal University, Gashua, Yobe State, Nigeria

Email: Nuraahmad212@yahoo.com

3 Department of Islamic Studies, Federal University, Gashua, Yobe State, Nigeria

Article Info:
Article history:
Received date: 01.03 .2020
Revised date: 12.04 .2020
Accepted date: 13.04 .2020
Published date: 10.06 .2020
To cite this document:
Yunus, J. H., Ahmad, N., \& Musbahu
S., T. (2020). Misconception About
Islam: As a cause for Emergence of
Insurgency in Nigeria, Boko Haram
Groups A case Study. International
Research of Shariah, Muamalat and
Islam, 2 (4), 01-08.

DOI: $10.35631 /$ IRJSMI.24001.

\begin{abstract}
:
Any misconception under Islam is considered as a misinterpretation of Islam despite the nature and disparity in understanding Islamic view scholarly and religious perspectives. The ignorance and non-religious individuals find it difficult to differentiate between renowned scholars and students ward manifested. It is recorded that scholars differ in terms of their views as experts, some speak on areas that are not their field of studies which generate faulty logic reasoning, deliberate distortion, and misinterpretations from the so-called scholars in Nigeria. Boko Haram emerged based on negative misconceptions and perceived some extreme views that are in conjunction and misleading towards Islam. To root out the insurgency from any society, there must be effective majors to be addressed, such as the root causes for the emergence, reasons for misconception, good governance and Justice within society and regulating the system of da'awa and dua'at (views preaching for and qualification of a preacher). Therefore, the paper will deliberate such issues through the writings of experts and suggest lasting solutions to such issues.
\end{abstract}

Keywords:

Misconception, Islam, Insurgency, Boko Haram, Nigeria

\section{Introduction}

In the name of Allah, most gracious and most merciful, all praises are due to Allah, the lord of the universe, may his peace and blessings be upon the Prophet Muhammad (S.A.W) his family and companions. Despite the effort been made by the enemies, Islam is the fasted growing religion in the world, and it is a divine religion of Allah, Quran is the mirror of Islam, one Copyright $\odot$ GLOBAL ACADEMIC EXCELLENCE (M) SDN BHD - All rights reserved 
cannot read it and remain the same, provided he reads it with sincerity of purpose and carefulness. Allah said in the Qur'an:



"This is a book, which we send down to you, full of blessing, so that they (all conscious, responsible beings) may ponder its verses, and that the people of discernment may reflect on it and be mindful" [Surat Saad, verse 29]

It is essential that for any person who wants a good interpretation of Qur'anic verses and to be demonstrated by its character, must be conscious, responsible and discernment, otherwise, will go wrong and create confusion, this is because of faulty logic and reasoning or invention of falsehood about Islam. Misconceptions mean the mistaken ideas or understanding, hence, misconception about Islam are misunderstandings held by people regarding what Islam is, and what Islam stands for (Charfi, 2005).

There are many factors involved in the emergence and proliferation of misconceptions about Islam. Misconception may stem from ignorance among Muslims, incorrect assumptions held by either Muslims or non-Muslims, stereotyping, emotive imagery in the media (such as in films, news reports, etc) which associate fear-evoking characters and acts with Islamic religiosity, the wide-scale publication of anti-Islamic writings, depends on faulty or biased sources of information, reactionary statements and behaviors of Muslims, injustice, extremism or "ghuluw" as describe in Qur'an:

$$
\text { "يا أَهل الكتاب لَا تغلوا في دينكم و لا تقولو ا على اللَّه إِلَا الحَقَّ" }
$$
"O people of the book! Don't go beyond the bounds in your religion, and do not say anything of God but the truth." [Surat Al-Nisa verse 171]

Indeed, laxity inappropriate application of Islam, some cultural norms in Muslim societies being wrongly associated with Islam and inaccurate or misleading translations of Islamic courses are among the issues lead to extremism in Islam. Misconceptions about Islam is indifferent aspects which among is extremism, and Jihad or Holy fighting. We will examine and highlight the history of insurgencies happened in Nigeria.

\section{Extremism}

Extremism is one of the biggest misconceptions about Islam, which was no doubt resulting from the constant stereotyping the Media gives to Islam. Such actions have no Islamic basis, often dictators and politicians will use the name of Islam for their purpose, one should try to get the source of Islam and separate what is the true religion of Islam from what is portrayed in the media (Esposito, 2003).

The principal known revolt or fear-mongering endeavor in Nigeria might be attributed to the development to free the Niger Delta individuals drove by Major Isaac Jasper AdakaBoro. Major Boro had a place with the Ijaw ethnic extraction in the Niger Delta district and, at the hour of his resistance, was an understudy at the University of Nigeria, Nsukka. His grievance was against the misuse of the oil and gas assets of the Niger Delta by both the bureaucratic and local governments in a complete dismissal of the residents of the zone. Boro framed the Niger Delta Volunteer Force (NDVF), and outfitted military gathering made out of 150 of his family. He immovably accepted that the individuals of the Niger Delta merited an increasingly impartial portion of the riches that collected from oil. To press the point, on 23 February 1966, the NDVF announced the Niger Delta Republic. The Republic endured just 12 days before the 
government military powers squashed the insurrection and captured Boro. He and his devotees were charged, attempted and detained for conspiracy. In any case, on the eve of the NigeriaBiafra war in July 1967, General Yakubu Gowon conceded them a reprieve. Boro enrolled in the government powers in the war against the revolutionary Biafran powers of OdumegwuOjukwu (Muzan, 2014).

\section{Nigerian Civil War}

The Nigerian common war (now and again called the Nigeria-Biafra War) was battled from 6 July 1967 to 15 January 1970. The war followed an overthrow of 15 January 1966, drove by military men of the Ibo-talking ethnic gathering, and a counter-rebellion of 29 July 1966, drove by military men for most of the Hausa-Fulani-speaking Northern district. An incredible social change followed these overthrows, including the obliteration of lives and property of people from the southern piece of the nation, especially those from Eastern Nigeria. Their family had been distinguished as pioneers of the main overthrow, which dispensed with unmistakable pioneers of the north, including Alhaji Tafawa Balewa, at that point Prime Minister of Nigeria, and Alhaji Ahmadu Bello, at that point Premier of Northern Nigeria. Colonel Odumegwu Ojukwu pronounced autonomy from the Nigerian Federation on 27 May 1967, naming the new condition of the Republic of Biafra. The common war that followed was likely the most annihilating that the African mainland has ever seen. (Mwekikagile, 2001).

\section{Movement for the Actualization of the Sovereign State of Biafra}

Over two decades after the finish of the Nigerian common war there developed the Movement for the Actualization of the Sovereign State of Biafra (MASSOB). This development is driven by Mr. Ralph Uwazurike, an attorney via preparation. This development has a firm root in the five South-East conditions of Nigeria that are home to the Ibo individuals. MASSOB has been accounted for to be very much furnished and there have been accounted for instances of showdown with the Nigerian police and military powers. MASSOB receives the Biafran national banner and this can be seen shown in the South-East political zone of the nation. The obvious presence of the Biafran banner in a region that would some way or another be A Nigerian sovereign area recommends that territory of Biafra still exists - in any event in the brains of the Ibos. MASSOB is a legitimate follow-up to the bombed exercises of the Biafran belligerents. The anguish of annihilation, combined with the agitated issues that keep on tormenting the Nigerian country, normally expands the past contentious posing into this new system fully expecting better chances to revive full-scale belligerency. MASSOB has so far never asserted obligation regarding any psychological oppressor act, nor has anybody been ascribed to its exercises up until this point. Be that as it may, MASSOB has presented and coursed Biafran cash notes as legitimate delicate. It has likewise given international IDs for residents of Biafra. MASSOB gave an 'official' articulation in 2009, anticipating the breakdown and crumbling of the Nigerian state by 2013. The announcement said that six republics are probably going to rise after the crumbling of Nigeria, to be specific, Biafra Republic (Ibo East), Arewa Republic (Hausa-Fulani North) and Oodua Republic (Yoruba West), and three other anonymous republics (Muzan, 2014).

\section{Movement for the Emancipation of the Niger Delta and Related Insurgencies}

Over 30 years after the end of Major Isaac Jasper AdakaBoro, there was a resurgence of the equipped dissent against the government and the worldwide organizations occupied with the oil business of the Niger DELTA. The majority of the furnished gatherings were comprised of raggedy, sick prepared, fretful young people, who are spread over the length and expansiveness of the Delta area. At its origin, this resurgence appeared to be strongly unfocused concerning who the objective ought to be - regardless of whether it should concentrate on the oil 
organizations, the administration, or the chieftains and their agents as the essential guilty parties in the apparent plan of dissents of advantages from oil tasks and the related wounds to the individuals and their condition. At first, in this way, there was incredible infighting among these equipped young people. This reached a crucial stage in the late 1990s, as the principle networks in Warri, Delta State, went into a full-scale equipped clash, one clan against the other. The war was focused on who should control the oil benefits coming to Warri, a focal point of oil creation, next in significance just to Port Harcourt, Rivers State, in the West African oil industry. The Ijaws, Itshekiri's and the Urhobos battled a damaging war for the spirit of Warri for over five years, however some way or another the acknowledgment that the shared adversary was the central government and its remote organization accomplices changed the crusade center from an internecine fratricide to a significant crusade against the administration. At this point, the anxiety of the young people had spread over the whole Niger Delta and was developing in complexity. (Muzan 1999). There are charges that degenerate government officials may have accidentally supported the procedure of militarization of the Niger Delta for individual reasons, oblivious to the results of their exercises. Prior on there had been different developments and activists who contradicted the apparent bad form the Niger Delta individuals had to shoulder by the administration and its oil organization accomplices. Much of the time, incorporating Umuechem and Ogoni in Rivers State, they were generally peaceful. (Muzan 1999).

\section{Oodua People's Congress}

The Western conditions of Nigeria are home to the Yoruba and the Oodua People's Congress (OPC), a patriot Yoruba association shaped in 1997. The establishing leader of the association is Dr. Fredrick Fasheun, and its aggressor perspectives are going by Ganiyu Adams. The association occurred as a characteristic result of the huge Yoruba fights which followed the demise of Chief MashoodAbiola, who was broadly viewed as the champ of the later repealed presidential appointment of 12 June 1993. Conflicts between the OPC and law authorization organizations, basically the police, heightened the action of a protester bunch inside the OPC, which at last split away to shape the Oodua Liberation Movement, in some cases additionally known by the name Revolutionary Council of Nigeria (RCN). This chip bunch became undeniably progressively activist in its tasks. This gathering contradicts Nigeria's bureaucratic arrangement of government and needs the Yoruba to withdraw from Nigeria and structure the sovereign Oodua Republic (Ighodaro, 2005).

\section{Northern Arewa Groups}

We presently go toward the northern piece of the nation known as Arewa. As of not long ago, the North had not seen any continued fear monger assaults which could be described as moving toward revolt. There were, be that as it may, brutal clashes in the north in the late 1970s and 1980s. These were savage, intra-strict crusades between various orders of Islam that brought about the passing of a few thousand individuals. The Maitatsine order drove by Sheik Muhmmadu Maruwa battled standard Muslims who would not acknowledge its way in Islam. Fortuitously, there were visit vicious and ridiculous intra-strict conflicts between individuals from Izalatubidi'atwaIkamatulSunna (Izala) and the TijaniyyaTariqaQuadriyyaTariqah (Tariqah) orders. The Izala, headed by Shiekh Abubakar Muhammadu Gummi, viewed some activities of Tariqah faction as un-Islamic and kept them from driving Juma'at petitions. This forbiddance prompted savagery that ejected. As indicated above the summary of the renowned insurgencies were found and past in the history of Nigeria, as all has a reason of emergence as indicated above for comparison happening and measures taken to address, different with the Boko Haram emergence and the ideology as will be discussed below. 


\section{The Emergence of Boko Haram Group in Nigeria}

Agbiboa (2014) Since the mid-2010s, the jihadist furnished gathering Boko Haram has used force and impact in North-eastern Nigeria and parts of bordering states in the Lake Chad bowl. The gathering pawed its way once more from a bombed uprising in July 2009 against the Nigerian government that left in excess of 1,000 dead, including the gathering's founder, Mohammed Yusuf, to reappear as an undeniable rebellion under the order of one of Yusuf's lieutenants, Abubakar Shekau, after a year (Muhammad \& Tahir, 2017). Throughout the following five years, and at an especially fast pace somewhere in the range of 2013 and 2015, the gathering held onto control of quite a bit of Nigeria's Borno State and started working in outskirt territories of neighboring Niger, Chad, and Cameroon. The association ravaged towns and besieged markets and houses of worship; just as mosques it considered "heathen". In April 2014 it organized the grabbing of 276 students in Chibok, Borno state. This mass kidnapping, which earned it worldwide judgment, was just one of a long arrangement of vicious episodes of striking fierceness (Schwartz, 2014).

However, beginning in 2015, Boko Haram ended up under expanding tension from the Nigerian military and its provincial partners, which took care of its inside divisions, making it shrivel in power. In March of that year, Boko Haram lost its self-announced capital, Gwoza, to Nigerian soldiers, and after some time, outstanding towns it had overwhelmed in Borno State fell go into government hands, constraining the gathering once more into places of refuge on the fringe of Lake Chad, in the Sambisa Forest and in slopes and mountains East of Gwoza.

Boko Haram's retreat exacerbated longstanding character conflicts and doctrinal contrasts inside the association. The gathering was as yet unblemished in March 2015 when Shekau swore loyalty to ISIS pioneer Abu Bakr al-Baghdadi and it took up the name Islamic State in West Africa Province (ISWAP). Be that as it may, after a year it broke in two. Following the lead of Mamman Nur and Abu Musab al-Barnawi, a child of Mohammed Yusuf, various senior pioneers split off from Shekau's powers. Nur and al-Barnawi's group, holding the name ISWAP, picked up acknowledgment from ISIS and pulled in a developing number of aggressors (Downey and Lucena 2018).

\section{Organizational Structure of Boko Haram}

The president (Amir ulAam) is the pioneer of the whole gathering (Late Muhammad Yusuf) he has two appointees (Na'ibul Amir ulAam I and II). Each state (where they exist) has its own Amir (Commander/Leader), and every Local government Area likewise has an Amir. Beneath the Local government Amirs are the rest of the devotees. They additionally sorted out themselves as indicated by different jobs, for example, fastens, police, and so forth. Notwithstanding, from the unequivocal substance of the talks and discussions of their pioneers and a portion of their evangelists, and their translation of the Qur'an and Sunnah, they respect non-individuals to be Kuffar (Disbelievers; the individuals who deny reality) (transgressors). They have complaints concerning any part of life - the monetary, political, lawful, and social framework, and so on - that isn't as per their translation of Shariah (Comolli, 2015).

\section{Ideology of Boko Haram}

According to Muhammad (2014) at the first, Boko Haram claimed to be Salafist neighborhood development in Borno State of North-Eastern Nigeria before it was transformed into a radical gathering in 2009. Salaf means the devout individuals from among the past age of the Islamic people group of devotees who are the partners of the Prophet (PBUH) and their supporters, for example, the initial three ages of Muslims and the individuals who followed their way in conviction and deed (Walker, 2012). The Salafida'wah literally signifies 'call', and right now 
alludes to calling to reality, lecturing and engendering of Islam - unadulterated and liberated from all augmentations, cancellations, and adjustments (Onuoha, 2014). It implies adherence to the way of the Prophet (PBUH) and the loyal and devout devotees of the past age of the Islamic people group and each one of the individuals who emulated their example in conviction, activities, and ethics (Hashim, 2014). Additionally, after the dynamic difference in its exercises in 2009, Boko Haram gets fit for doing significant assaults including suicide and meaning bombs The gathering confounded a few pieces of Islamic educating in which they think about cooperation with Western culture as a transgression. The gathering is against the exercises of standard Islamic researchers (Bartolotta 2011). Based on the ideology and the activities of the above groups of insurgencies the Boko Haram Insurgence was worst and downfall the country economic growth especially the northern region of the country

\section{Eradication of Insurgence in Nigeria, ways and Solutions}

Harmony is related in the Qur'an with God, making it the characterizing highlight of the existing proposed for humankind, to be completely acknowledged eventually in the following life. Islam perceives defilement as endemic to mankind and the requirement for power to keep up political and social harmony, inside and across social orders. Early life stories of the Prophet Muhammad propose that while he battled, he constantly looked for a fair harmony-once in a while over the fights of his partners (Ana, 1998). Impressive disarray connects to the idea of jihad, which can be interpreted as either otherworldly or furnished battle. During the early hundreds of years of Islam, researchers set moral points of confinement on war-production. Goals must be unadulterated, and not simply self-intrigued, and the utilization of power must be completely vital, for instance, to secure the strict network, save equity, or safeguard an area. Along these lines, jihad to expand the residence Islam was driven more by royal than by strict contemplations. The Qur'an denies intimidation in strict undertakings: "There is no impulse in religion." (Qur'an 2:256) and slaughtering an existence without cause is identical to "executing the entire human race" (Qur'an 5:32). Present-day calls for sacred war against the unbelievers, enunciated by Osama canister Laden and others, are inconsistent with the Islamic convention and completely decried by driving Muslim researchers. Islam is likewise home to a radical current, most lavishly created inside Sufism. Every person has an exceptional spot in Allah's creation regardless of what confidence or conviction an individual decides to affirm. Not exclusively are generally people offspring of Adam to whom Allah orders the holy messengers to bow (Q, 2:34), however, every human has a soul Allah inhaled into that person. Allah says "... and afterward He frames you as per what he is intended to be, and inhales into him of his soul" (Q, 32:7-9)

The Qur'an clarified how its message is to be spread. The Prophet Muhammad (SAW) was told by Allah, "You just should declare... ... "(Q, 36:17), "Welcome all to the method for your Lord with intelligence and delightful lecturing....." (Q, 16: 125)

\section{Conclusion}

Based on the findings of the research and perception of the ideology of misinterpretation on the impact of support on the insurgency which affected the society and ummah of Islam. However, the study revealed that scholars' interpretation is one of the fundamental reasons for generation misconception and misinterpretation amongst their followers encourage intellectual stimulation amount the government to regulate and fight against such scholar and their respective members. The finding also revealed the good condition amongst the society with the respective leaders and those Intellectual stimulations use the vulnerable life of the community together courage and sympathy to lead the society with negative perception and understand of the right paths participatory activities. 
Furthermore, the study also revealed any path of the country have their respective problem as discussed as Northern Nigeria were strong enough and sensitive in the religious perspective, any view which in conjunction with government directive or provocative government masses will welcome it and participate it as they feel vulnerable and neglect by the government. It can be concluded that the preachers (dua't) should be regulated and develop a body that will continue supervising the activities and qualification of the preacher and what are they preaching to avoid misconceptions and misinterpretation of any religious divine message for the future occurrences to support activities and strengthen the religious message.

The research also investigates the social recommendations for social interaction for future occurrences of such activities of insurgency and deliberates through suggesting a lasting solution for the Government to adopt as the previous recommendation was given for regulation of preachers.

\section{Local Security Governance}

The government should set-up a network ought to be used for community Safety Groups/Neighborhood Watch Groups. Network individuals realize their networks superior to the security offices. They have to take an intrigue and associate with security associations. There should be backing and insurance for the networks that are supporting the security organizations. Residents approach the government and the military to structure a strong strategy and arrange a bound together layout with nearby networks for interest in security and insight gathering.

\section{Education and Literacy Program}

Education has become a significant in the society, lack of education in Nigeria, most youngsters have gotten effectively helpless to control and enlistment into criminal and radical gatherings. Even though the privilege to training is one of the essential privileges of each Nigerian, access and qualification to this privilege is not achieved. To lessen the quantity of individuals who are probably going to fall prey to radical lecturing and enlistment into fierce gatherings, essential and auxiliary instruction ought to be made free and obligatory for each youngster in Nigeria. Along these lines, what is required is for the neighborhood and state government to summon adequate political will to convey quality and open training to more children in Northern Nigeria through improved allotment and sensible use of assets in the instruction division.

\section{References}

Agbiboa, D. E. (2014). Peace at Daggers Drawn? Boko Haram and the state of emergency in Nigeria. Studies in Conflict \& Terrorism, 37(1), 41-67.

Ana, S. (1998). Wonder-full Islam: How to preserve our Sense of wonder.

Bartolotta, T. V., Taibbi, A., Midiri, M., Matranga, D., Solbiati, L., \& Lagalla, R. (2011). Indeterminate focal liver lesions incidentally discovered at gray-scale US: role of contrast-enhanced sonography. Investigative radiology, 46(2), 106-115.

Charfi, M. (2005). Islam and liberty: The historical misunderstanding. Zed Books.

Comolli, V. (2015). Boko Haram: Nigeria's islamist insurgency. Oxford University Press.

Downey, G. L., \& Lucena, J. C. (2018). Engineering selves: Hiring in to a contested field of education. In Ethics, Politics, and Whistleblowing in Engineering (pp. 25-43). CRC Press. 
EIE (2017) "Citizen Solutions to end Terrorism" macarthur foundation \& open society initiative for west africa https://storify.com/eienigeria/citizenssolutiontoendterrorism

Esposito, J. L. (2003). Unholy war: Terror in the name of Islam. Oxford University Press, USA.

Hashim, A. S. (2014). The Islamic State: From al-Qaeda Affiliate to Caliphate. Middle East Policy, 21(4), 69-83.

Ighodaro, O. O. (2005). The political economy of oil and the Niger Delta crisis. Northern Arizona University.

Mohammed, K. (2014). The message and methods of Boko Haram. Boko Haram: Islamism, politics, security and the state in Nigeria, 9-32.

Muhammad T. Tahir A.K (2017) Psychological Perception of Teachers on Jama'atul Ahlu Sunna Lidda'awati Wal Jihad (Boko Haram) Insurgency in the Affected Areas in Maiduguri, Nigeria. The International Journal of Humanities \& Social Studies. ISSN 2321-9203 pg 5-12

Muzan, A. O. (1999). Conflicts, disputes and strife in the Niger Delta oil industry: A causal analysis. Nigerian Journal of Jurisprudence and Contemporary, (53).

Muzan, A. O. (2014). Insurgency in Nigeria: Addressing the causes as part of the solution. African Human Rights Law Journal, 14(1), 217-243.

Mwakikagile, G. (2001). Military coups in West Africa since the sixties. Nova Science Pub Incorporated.

Onuoha, F. (2014). Boko Haram and the evolving Salafi Jihadist threat in Nigeria. Boko Haram: Islamism, politics, security and the state in Nigeria, 2, 158.

Schwartz, H. (2014). The culture of the copy: Striking likenesses, unreasonable facsimiles. mit Press.

Walker, A. (2012). What is Boko Haram? (Vol. 17). Washington, DC: US Institute of Peace. 